\title{
The Architectural Image of the East Prussian Manor House of the XVII - First Half of the XX Century (Modern Kaliningrad Region of the Russian Federation)*
}

\author{
Irina Belintseva \\ Branch of the Federal State Budget \\ Scientific Research Institute of the Theory and History of Architecture and Urban Planning \\ Institution -Chtral Scientific-Research and Project Institute of the Construction Ministry of Russia" \\ Moscow, Russia \\ E-mail: belinceva@bk.ru
}

\begin{abstract}
The article is devoted to specific architectural and artistic features of the manor houses of the former East Prussia that existed or survived on the territory of the modern Kaliningrad region. The author analyzes the characteristic stylistic features inherent in the early estates of this Baltic region (XVII century), based on the traditions of serf architecture. The modest estates of the landowners of the era of classicism and Biedermeier have replaced the palaces of the aristocracy of the early XVIII century. In the first half of the $X X$ century neo-Gothic and neo-Baroque styles have become the most prevalent architectural styles.
\end{abstract}

Keywords-East Prussia; Kaliningrad region; manor houses; architecture; stylistic features; neo-gothic; neo-baroque

\section{INTRODUCTION}

The estates of the former East Prussia in the Kaliningrad region are still insufficiently studied. The estate heritage of East Prussia is almost lost nowadays. According to my calculations, there have been more than 400 estates with manor houses and numerous outbuildings only in the present Kaliningrad region. The number of remaining rural manor houses, often surrounded by wild parks, is small - there are about 60 of them left. There are also estates that have lost the main house and are represented by only half-ruined outbuildings (about 57 complexes).

\section{THE ARCHITECTURAL APPEARANCE ORIGINS OF THE EARLY MANOR HOUSES}

There are several terms to refer to the manor house in the

*The Reported study was Funded by Science and Technology Development State Program of the Russian Federation for years 2013-2020 Program of Fundamental Research of State Academies of Science for years 2013-2020, within the Program of Fundamental Researches of Ministry of Construction, Housing and Utilities of the Russian Federation and Russian Academy of Architecture and Construction Sciences; the Research Project 1.2.26/1.2.39 Germany
German literature. The Palace (das Schloss) - "an unprotected or only slightly fortified residential building for aristocrats. Such buildings were designed for the lush and luxurious living. This type has become widespread in the XVI-XIX centuries "[1]. In the first decades after the secularization of the Teutonic Order, which has existed in the XIII - the beginning of the XVI centuries on the territory of the Kaliningrad oblast and Pomeranian Voivodeship (Poland), and formation of the secular Duchy of the Hohenzollern dynasty in 1525, numerous former fortresses (Burg), inherited from the Order state, have been rebuilt as the noble families' dwellings. Another type was the more modest manor house (Herrenhaus) which has been usually located in a park or a farmland and represented a relatively small residential building for the owners of the estate, engaged in an economic activity.

Early rural manor houses had the form of a closed 1-2 storey block sometimes complemented by towers. They had small window openings, without any decorations and signs of luxury. The houses of notable families in Gallingen, finished in 1589, and belonged to the Eulenburg counts (Galiny, Olsztyn Voivodeship, Poland, preserved), a house in Wicken (Klimovka, Pravdinsky district, Kaliningrad region, not preserved.), erected in 1676, allegedly, by the famous German architect Friedrich David Gilly (1772-1800.) Truntlack (Shevtsovo, Bagrationovsky district, Kaliningrad region, not preserved.), and many others similar in appearance are among the oldest buildings. Their distinguishing feature was the likening of simple fortifications of the middle ages and the maintenance of the long-established ancient appearance for centuries, despite changes in architectural fashion. However, R. Dethlefsen, the restorer on the post of the custodian of monuments of East Prussia claimed in the early XX century, that "the houses of landowners did not go back to the type of fortifications, but to the peasant house. Like a peasant, a rich landowner in East Prussia built his home as an elongated rectangle in the plan, with an entrance in the center of the long side and a large 
entrance lobby, from which the living quarters of different purposes went. If necessary, wings for new family members were attached, so that the building received the shape of the letter $\mathrm{U}$ or $\mathrm{H}$. A protruding risalit with an underlined entrance was a rare element, the idea of which also goes back to the peasant house" [2]. The author of the several estate architecture studies - C. von Lorck emphasized that "East Prussia has calm, balanced and simple forms of local houses, which reflect the prevailing simplicity of life and the rigor of existence" [3].

Truntlack rural estate originally belonged to the counts von Schlieben and subsequently to their descendants (von Wernsdorf, von Heyking, von Horn, etc.), and represented a typical East Prussian farmstead, formed over the centuries. The main house served as the center of the estate's architectural complex. It was built in the early seventeenth century and has persisted without significant rearrangements until the second half of the XX century. The author of the architectural project is unknown. Probably one of the first owners of the estate Dietrich V von Schlieben has brought masters involved in the capital rebuilding of his castle in Königsberg, to the construction works between 1629 - 1637 [4]. As a similar lordly dwelling, the building represented a rectangular planned volume - a powerful, two-storey stone block with an attic floor, with a high-pitched roof, which has been popular in the region of the Baltic sea. Two-storey towers under the four-pitched roofs, one of which housed a church adjoined the building from the park facade. Such three-dimensional composition, undoubtedly, unites the local houses of this type with the previous fortress construction.

The center of the front facade was originally marked by a staircase, going in two directions along the front wall, which at the beginning of the XX century has been replaced by a wide-open porch with one straight march. There was a persistent tradition in the province to arrange a manor house in such a way that its front facade and a comfortable porch have been turned towards the household yard, so it was easier to observe the life flowing there.

\section{REPRESENTATIVENESS AND SIMPLICITY OF THE MANOR HOUSE: FROM BAROQUE TO BIEDERMEIER}

The most significant and representative palaces of the XVIII century in the Kaliningrad region have not survived, although some of them have stood until the end of the Second world war, such as Friedrichstein (Kamenka, Guryevsky city district). Friedrichstein belonged to one of the most famous families of East Prussia, the Dönhoff rooted in the XVI century. The estate has been acquired by count Friedrich Dönhoff, who held high posts at court [5] from the Great Prince-elector in 1666. There is an assumption that the Bernini's project for the eastern facade of the Louvre in 1664-1667 which has been often used in the BrandenburgPrussian architecture of the time has been used as a model for the appearance of the manor house. A. Ulbrich, who published in 1932 the book "The Art History of East Prussia from the Order Period to the Present Time", believed that Friedrichstein has been built by the French architect Jean de Bodt (1670-1745) [6]. The same opinion is shared by other researchers, including the first researcher of the estate culture of East Prussia C. von Lorck [7]. French master John von Collas (1678-1753) [9] has supervised the construction of the Palace in 1707-1714. Like many rich manor houses of East Prussia of the first half of the XVIII century, it holds the imprint of a transition from Baroque to Classicism [10].

In contrast to the imposing palaces of the wealthy courtiers of the beginning of XVIII century aristocratic dwellings of not so well-born landowners of the era of Classicism and Biedermeier had a simple rational form. It can be noted that a kind of return to the simplicity of the first manor houses took place at that time. The rational and thrifty landlords paid most attention not to the decoration of their homes, but to the construction of farm buildings - stables, cowsheds, pigsties, etc., which have rivaled the richness of forms and sizes of manor houses, and even surpassed them.

In the estate of Hochlindenberg (Podlipovo, Pravdinsky district) a typical example of the Prussian manorial home of the late XVIII - mid-XIX century, which belonged to wealthy but not aristocratic owners remained [11]. Until the end of the Second World War, the estate has been owned by the Kreutzberger family, which had Salzburg roots. The original house of the XVIII century was a one-storey brick building, plastered and covered with a gable roof. After the construction of the new building it has been turned into a kitchen wing and in the pre-war years it has usually been called the "Old House". The "Old House" was connected to the main building by a wide cross passage - a corridor with exits to the street and to the garden.

A long one-storey building of the XIX century with the upper half-floor (or rather quarter-floor") and a gable sloping roof, once tiled, and now covered with the wavy slate usual for Russia, bears the signs of the simplest version of the Biedermeier era construction technique: slightly protruding two-axis two-storey ledge-risalit marks the central part of the house. It is slightly offset from the symmetry axis and is completed by a triangular pediment with round windows framed by red brick in their upper parts. The same windows adorn the pediment of the wall on the right side of the house. Low openings of the upper mezzanine windows, illuminating the space under the roof are barely visible above the windows of the first floor. C. von Lorck noted that the shape of the "quarter-floor" under the gable roof is "a C.F. Schinkel's discovery, which he first used in his building of the Construction Academy in 1831-1835.This "quarter-floor" has become the leitmotif in East Prussia in 1840-1870." [12]. Round, square or horizontally elongated windows located under the roof are characteristic for the architecture of mezzanine floors in the province.

The main facade of the house, which has once stood in a green front garden, and now right on the street, has been once highlighted by the long-lost protruding wooden open veranda with a gable roof, decorated with wooden details. The wooden veranda adjacent to the main entrance, has become the distinctive feature of the local houses of East Prussia since the mid-nineteenth century. In those buildings, whose owners have not sought to accentuate the representativeness of their homes and tended to the rationality and convenience, the wooden entrance extensions 
replaced typical four-column porticoes. Open verandas in some of the houses were designed as porticos with wooden pillars, crowned with the likeness of the capitals, such as in a residential house in the former estate of Kurland (Vasilevka, Ozersky urban district, not preserved). The example of a well-preserved wooden veranda with twisted columns can be seen on the park side of the house in the Pesochny in Pravdinsky district (the former estate of Althof, Bartenstein district). Verandas have been usually completed with a gable roof with a triangular pediment decorated with carved details, which can be often found in wooden architecture and have been recorded in the books of samples.

\section{NEO-GOTHIC AND NEO-BAROQUE IN THE ARCHITECTURE OF RURAL ESTATES OF THE FIRST HALF OF THE XX CENTURY}

In the middle of the XIX - early XX centuries the estate construction continued and old manors have been often rebuilt. They were adapted to the growing requirements for comfort, new aesthetic tastes and economic needs of the owners. Among the remarkable rural estates of the turn of the century was the estate in Korben (Krasnoflotskoe, Zelenograd district).

The Korben estate has been bought in November 1895 by a merchant Gustav Adolf Georg Siebert (1865-?) [13]. The local house and an extensive complex were built by the famous East Prussian architect Friedrich Heitmann (18531921) [14]. The development of the estate began with the construction of huge farm buildings in the neo-Gothic style, which can still be seen in a dilapidated condition.

At the moment of the purchase in the late XIX century the manor house has been his best building, but the Italianate style of the old building with a flat roof was not consistent with neo-Gothic appearance of new farm buildings, so the palace has been rebuilt in 1905 . The house was designed by F. Heitmann in the spirit of local brick Gothic, with stylized elements of medieval architecture (which have not survived.). The high steep roof was decorated with a turret covered with copper. According to the memories of the last inhabitants of the palace, "from there you could see the Curonian lagoon with its sailboats, a spit with white sand dunes, and even more distant surroundings" [15].

In the first half of XX century the architecture of "about 1800 s style" has been promoted in East Prussia. NeoBaroque of the first half of the XX century is a little-studied phenomenon that arose in Germany under the influence of the ideas of the theorist of architecture Paul SchultzeNaumburg (1869-1949), who called to return to the harmonious forms of the architecture of "around 1800s" style [16]. Neo-Baroque buildings have been built then more on the models of Italian Palazzos, rather than reproduced the forms of the local houses of the Baroque era.

Among well-preserved manor houses in neo-Baroque style there is the estate in Bledau (Sosnovka, Zelenograd district). Max Johann Otto Adolf Tortilowicz von Batocki-
Friebe $^{1}$ (1868-1944.), was the owner of the palace which from 1895 and until his death he has successfully managed. Initially, it was planned to reconstruct and expand the already existing old house in restrained forms of classic architecture (designed by architect Friedrich Franz von Hochberg). But the house has burned down in 1913 on a September stormy night and has been renewed in neoBaroque style on a different place, in a large park, designed by the same architect (1921).

Architect F. F. von Hochberg (1875-1954), was raised in the family castle of Ronstock (former German province of lower Schlesien, Roztoka, Poland, preserved) in the aristocratic intellectual and artistic environment, which influenced his subsequent activities [17]. His own old family castle, the "Hochberg", was glorified as the example of highart architecture in the well-known book by P. SchultzeNaumburg. Palaces and mansions were the specialization of the master. His biographer F. Schubert explained that it was his habit from the childhood to live in palace conditions, so he had an excellent knowledge of the needs of his high-born customers. The two-storey manor house preserved in Sosnovka has the traditional $H$ " letter shape. To achieve greater representativeness, the house has been built on a stone basement floor and completed by a high two-storey attic roof with french oval "bull's eye" windows enclosed in a rich frame with volutes. The facades are divided by flat wide pilasters-blades without capitals, stretching to a height of two floors. The main facade is emphasized by a semicircular ledge, while the park facade is flat and its central axis is highlighted by the triangle of the pediment with an oval reclining window in the center of the pediment field. In front of the entrance there has been an open terrace stretching the entire width of the Central part of the building. The thoughtful interior layout of the house was discussed with the customer and has been made very rationally.

\section{CONCLUSION}

The manor houses and outbuildings of the former East Prussia over the centuries have demonstrated contradictory aspirations of customers and architects to meet the style trends of their time, and at the same time - to preserve the inviolability of the traditional Prussian ideals of power, simplicity, and economy. It should be noted that the estate cultural heritage of the former East Prussia in the Kaliningrad region requires further research.

\footnotetext{
Since 1907, von Batocki was the Chairman of the agricultural Department of the government of East Prussia, since 1914 he has been the President of the province and became famous during its post-war reconstruction. In 1919, he has retired and headed the Institute of East German economy for many years.
} 


\section{REFERENCES}

[1] C. von Lorck. 'Castles and Palaces'. in German. Frankfurt, Wolfgang Weidlich, 1965. p. 11.

[2] R. Dethlefsen. 'Town and contry houses in the East Prussia'. in German. München, 1918. p. 53-54

[3] C. von Lorck. 'East Prussian farmhouses. Construction and culture content. With a descriptive directory of farmhouses. 138 pictures and 20 text sketches'. in German. Kitzingen / Main, Holzner-Verlag, 1953. p. 57.

[4] W.D. Wagner. 'The Rittergut Truntlack. 1446-1945. 499 years history of an East Prussian estate'. in German. Vol. 1-2. Husum, Druck- und Verlagsgesellschaft mbH u. Co. KG, 2014. p. 194.

[5] K.Heck K., Ch. Thielemann. 'Friedrichstein. The castle of the counts of Dönhoff of east Prussia'. in German. München, Deutscher Kunstverlag, 2006. p. 32.

[6] A. Ulbrich. 'Art history of east Prussia from the time of the order to the present' in German. Königsberg, Ostpreussische Druckerei und Verlagsanstalt, 1932.p. 175.

[7] C. von Lorck. 'East Prussian farmhouses. Construction and culture content. With a descriptive directory of farmhouses. 138 pictures and 20 text sketches' in German. Kitzingen / Main, Holzner-Verlag, 1953.

[8] K. Heck K., Ch. Thielemann. 'Friedrichstein. The castle of the counts of Dönhoff of east Prussia'. in German. München, Deutscher Kunstverlag, 2006. p. 105.

[9] C. von Lorck. 'East Prussian farmhouses. Construction and culture content. With a descriptive directory of farmhouses. 138 pictures and 20 text sketches'. in German. Kitzingen / Main, Holzner-Verlag, 1953. p. 64.

[10] I.V. Belintseva. Manor complexes of the Kaliningrad region: problems of study // Russian Manor. Collection of the Society for the Study of Russian Manor / red.-sost. M.V. Nashchokina. - St. Petersburg: Kolo, 2018. C. 375-386,

[11] W. D. Wagner. 'Goods in the district Gerdauen. Description of the goods of the administrative district Gerdauen / East Prussia'. in German. Berlin, 1996. Vol. 1. Hochlindenberg. pp. 53-70. p. 54.

[12] C. von Lorck. 'East Prussian farmhouses. Construction and culture content. With a descriptive directory of farmhouses. 138 pictures and 20 text sketches'. in German.Kitzingen / Main, Holzner-Verlag, 1953. p. 46.

[13] E. Siebert-Korben. ' Manor Korben // The County of Samland. A book of the former counties of Königsberg and Fischhausen. Compiled by Paul Gisovius'. in German. Würzburg, Holzner Verlag, 1966. pp. 301-307. p. 301.

[14] I.V. Belintseva. Architect Fritz Heitmann - between neogothic and art nouveau. // Questions of the general history of architecture. Personality. The Epoch. Style. Moscow: LENAND, 2012. pp. 220242.

[15] E. Siebert-Korben. 'Manor Korben // The County of Samland. A book of the former counties of Königsberg and Fischhausen. Compiled by Paul Gisovius'. in German . Würzburg, Holzner Verlag, 1966. pp. 301-307. p. 305.

[16] P. Schultze-Naumburg. 'Culture work'. in German. Vol. 1-9. München, 1901-1917.

[17] W. F. Schubert. 'Duke Friedrich Franz von Hochberg'. in German. Görlitz, 1921. 